Bed " sequence is developed as at May Hill, Old Storridge Common, Ankerdine Hill and in Shropshire : complete Cambrian successions are often present in these areas. To the east, at the Gullet, in West Malvern and Walsall, Rubery and Tortworth, early Upper Llandovery beds do not occur and the Cambrian is partially or completely eroded. The controlling factor of these differences was vertical movement along the Malvern Line in pre-Upper Llandovery times. This Line appears to be a major structural feature and has been active at different periods, although its exact position at the surface has varied from the west side to the east side of the present Malvern Hills, and movement along it has been different at different times. This line is subparallel with the Church Stretton Line and like it, seems to have controlled sedimentary patterns from time to time.

Phipps and Reeve have argued that the quick change in stratigraphy from the Gullet-West Malvern area to the Cowleigh Park area is proof of a postSilurian fault on the west side of the Malvern Hills and that the Cambrian sequence and the Cowleigh Park Beds are cut out by the fault. My conclusion is that these units are missing through erosion and non-deposition.

\title{
REFERENCES
}

Reading, H. G., and A. B. Poole, 1961. A Llandovery Shoreline from the Southern Malverns. Geol. Mag. XCVIII, 295-300. 1962. Malvern Structures. Geol. Mag. XCIX, 377-9.

ZIEGLER, A. M., 1963. The Stratigraphical Palaeontology of the Upper Llandovery Rocks in the Southern Part of the Welsh Borderland. Unpublished D. Phil. thesis at Oxford University.

Division of the Geological Sciences,

A. M. ZIEGLER.

California Institute of Technology, Pasadena, California.

June, 1964.

\section{THE LUXEMBOURG COLLOQUIUM}

SIR,- - The report on the Luxembourg Colloquium on the Jurassic by Dr. Lloyd (Geol. Mag., 101, 249-59) is of importance not only to specialists in the geology of the Jurassic but to all who are interested in the whole complex of problems in stratigraphic correlation.

I discuss in detail elsewhere (Palaeontology, 8 , in the press) the nature and status of the biostratigraphic zone and stage in relation to so-called " timestratigraphy", and wish here to refer only to some general points raised in Dr. Lloyd's paper. The first concerns the apparent contradiction implied by the statements (1) that " by implication, no element of time need be considered in formulating a zone" ; and (2) that "Zones were isochronous throughout their area of development" (op. cit., p. 257).

I prefer at this stage to disregard the " Copenhagen rules", and to consider the problem $a b$ initio. It is clear from the difficulties that have arisen in various recent attempts to codify the fundamentals of stratigraphic classification that at least one fallacious assumption is being rather generally made. This fallacy concerns the boundaries or limits of biochronologically significant zones. (I deliberately refrain here from attempting a rigorous definition of the term zone. It will be enough to emphasize that the kind of zone under discussion is used in "recording the passage of time"-i.e. it has to do with some sort of chronology ; it is defined mainly in terms of organic assemblages ; and it has a meaning in relation to other zones of the same kind from which it can be distinguished). It appears to arise through a failure to consider the essentially relative nature of the "time-scale" based on a succession of discrete zones. This relativity of zones must of necessity imply that no zone, with upper and lower boundaries, can exist by itself, or can be given precise correlational definition in isolation, as if it were, for example, a number. 
In reality, while it is true that the presence of a zone can be demonstrated in isolation, the boundaries of that zone can only be demonstrated in the presence of the preceding and succeeding zones in vertical sequence. A zone, in other words, is a real entity if and only if it is the central member of a triplet.

My second point arises from Dr. Lloyd's statement (op. cit., 251) that the " limits of a stage in the vertical sense are artificial. . . . stages stand in direct hierarchical relationship to zones and ... are distinguished in terms of included zones."

Care is needed in the use of terms like "hierarchical" since many authorities appear to believe that zones are subdivisions of stages, whereas I assume that Dr. Lloyd follows Arkell in regarding stages as " groups of like zones" (Arkell, 1956, 7 and 9). I agree with this usage, but I cannot agree with the notion that the limits of stages in the vertical sense are artificial. Since a stage is a group of like zones it follows that the limits of a stage must coincide with two of the limits (or boundaries) of its component zones, and that these must be defined in terms of adjacent zones. Dr. Lloyd himself adumbrates, perhaps unconsciously, this conclusion, when he writes (op. cit., 256) : "It was further felt that evidence from the Jurassic alone was not sufficiently conclusive to allow the fixing of the upper limit of the system ..."

From these logical requirements in defining the stage in terms of zones, and the zone in terms of adjacent zones, there arise doubts as to the desirability of giving formal priority to stages which cannot be adequately defined in their original type-area owing to the incompleteness of the record. Thus, in the case discussed by Dr. Lloyd, the Portlandian cannot be satisfactorily delimited, and a similar situation exists in relation to the Ludlovian in its type area. It might be a useful convention to have some term like "para-stage" to indicate a body of strata known on palaeontological evidence to "belong to " a certain formal stage, but lacking completely definable boundaries.

Since long-range correlation depends on the use of stages it is clear that these must be satisfactorily defined. However, it is also clear that equally valuable type-areas or type-sections are those in which stages of one regional sequence overlap those of another, or in which there are zones common to both. Since there is no necessity for inter-zonal-and hence inter-stage-boundaries in different regional sequences to coincide (unless one accepts the possible synchroneity of certain kinds of diastrophic event) special attention should be given to cases in which this does occur. Thus in the case of the Kimmeridgian/ Portlandian problem it would appear that the Fourth solution of Enay (Lloyd, op. cit., 254), in which the ubiquity of the Gravesia zones is made the basis for defining the base of the Volgian (or Tithonian), should have priority over the Fifth solution, in which a boundary is chosen at a N.W. European "break" unrecognizable elsewhere.

It may become desirable in the future to distinguish between stages which owe their individuality to local accidents of diastrophism or developmental rate in organic assemblages, and those which, because of their involvement in overlaps of special value in correlation, are selected to give their name to, and act as reference points for, particular segments of the general chronological sequence. Thus the statement "The British pre-albani Volgian is distinguished as the Dorsetian "would convey precise information to the stratigrapher familiar with the definition of the Volgian stage with a subGravesia lower limit.

As the sequence of well-defined zone-triplets is built up it will tend more and more closely to the condition of a continuum. Chrono-stratigraphic divisions of the present stage or system type will thus come to have progressively less real significance, and will have to be recognized as more or less arbitrarily chosen segments of the continuum.

In conclusion I hope Dr. Lloyd will allow me to hope that in any future publications he and his Luxembourg Colloquium colleagues will (a) present their tabulation in the stratigraphically conventional "right way up"; and (b) dispense with the lithostratigraphic terms Lias, Dogger and Malm, which have no place in any generalized chronostratigraphic succession. 


\section{REFERENCES}

Arkell, W. J., 1956. Jurassic Geology of the World. Edinburgh : Oliver and Boyd.

Lloyd, A. J., 1964. The Luxembourg Colloquium and the Revision of the Stages of the Jurassic System. Geol. Mag., 101, 249-59.

T. G. Miller.

DePARTMENT OF GEOLOGY,

UNIVERSITY OF KEELE.

30th July, 1964.

SiR,--I very much welcome the further publicity given to the Luxembourg recommendations by Dr. Lloyd in his recent paper in your journal, and also his excellent survey of the bearing of those recommendations on current British usage and on the Copenhagen report on Stratigraphic Classification and Terminology.

As Dr. Lloyd points out, the Luxembourg Colloquium was organized under the aegis of the Mediterranean Mesozoic Committee of the Stratigraphic Commission of the International Geological Congress, and it is therefore appropriate to draw the attention of your readers to the activities of that committee and of the British Mesozoic Committee since the Colloquium.

The Mediterranean Mesozoic Committee (which covers all those countries having Mesozoic rocks in Europe, the Middle East and North Africa) has met on three occasions : at Bucharest (September, 1962), Cracow (September, 1963) and Cassis, near Marseilles (May, 1964). At those meetings, among other matters, the Luxembourg recommendations were considered and the relevant national committees were asked to express their opinions on them. At the last meeting, all the various recommendations and counter-recommendations were considered together and put into an agreed form for presentation to the Stratigraphic Commission at New Delhi in December.

In connection with the request mentioned above, the British Mesozoic Committee met in February, 1963, to consider the Luxembourg recommendations. Their provisional views were later published (together with the original recommendations) in Nature (Ager, 1963). This was intended chiefly to give other Mesozoic workers an opportunity of considering and expressing their opinions on these matters. In view of the interest and conflicting opinions aroused by this publication (especially among those who had not been able to attend the Luxembourg colloquium) it was decided to hold a general discussion meeting to guide the British committee in framing their final recommendations. This was held at the Geological Society on the 26th February, 1964. The conclusions reached after that meeting were again communicated to Nature and should be published very shortly (Ager, 1964).

Dr. Lloyd quite rightly draws attention to the anomalous relationship between the "Copenhagen principles" and the "Luxembourg recommendations". The attention of the international committee was drawn to these anomalies at Cassis by the British delegation (Dr. L. R. Cox and the writer), and it was agreed that notwithstanding the Copenhagen "Statement of Principles" (Hedberg, 1961), Mesozoic stages must in practice be defined in terms of faunal zones (i.e. assemblage zones in the sense generally understood among British Mesozoic workers).

As a purely personal opinion, it seems to the writer that the Copenhagen principles, with their complete separation of Lithostratigraphy, Biostratigraphy and Chronostratigraphy at all levels, are somewhat divorced from reality and practicality. It is unfortunate that British stratigraphers and palaeontologists are, by implication, committed to these principles without their ever having been formally considered or discussed in this country, and without British stratigraphic thought being truly represented at the international discussions. There is need for a national committee on stratigraphical nomenclature in Britain, such as exists in almost every other major country, to ensure that our agreed views on these matters are adequately presented to the relevant international bodies. There is in fact a particular moral obligation on British 
geologists to do this, since so many of the world's stratigraphical terms originated in this country.

At New Delhi in December, both the Luxembourg recommendations themselves and the slight modifications of them proposed by the Mediterranean Mesozoic Committee, will be presented to the Stratigraphic Commission. It is hoped that firm rulings will then emerge on the subdivisions of the Jurassic and that these will lead the way for other parts of the stratigraphical column. It is also particularly to be hoped that all British Jurassic specialists, and especially those official bodies concerned with stratigraphy, will then accept and follow these rulings in spite of any temporary inconvenience, unfamiliarity or personal disagreement about arbitrary limits.

\section{REFERENCES}

Agar, D. V., 1963. Jurassic Stages. Nature, 198, No. 4885, 1045-1046. 1964. The British Mesozoic Committee. Nature, in the press.

Hedberg, H. D., 1961. Stratigraphic Classification and Terminology. Internat. Geol. Congress, Rep. 2Ist Session, Norden, 1960. Part XXV.

Lloyd, A. J., 1964. The Luxembourg Colloquium and the Revision of the Stages of the Jurassic System, Geol. Mag., 101, 249-259.

D. V. AGER.

DePARTMENT OF GEOLOGY,

Imperial College of Science and Technology, LONDON, S.W. 7.

$J u l y, 1964$.

\section{NON-EQUIVALENCE OF DISTRIBUTION COEFFICIENTS AND TIE- LINES OF COEXISTING PYROXENES}

Sir,-Further to some previously published words of caution on the use of distribution coefficients to express the partition of iron and magnesium between coexisting pyroxenes (O'Hara and Mercy, 1963, pp. 305-310) I wish to draw attention to an error which is gaining ground in the literature.

Bartholomé (1961) presents two figures allegedly representing tie-line orientations for coexisting pyroxenes having particular values of $K_{t}$, the distribution coefficient ( $=1 / K D$ where $K_{D}$ is the distribution coefficient calculated by Kretz, 1961) with the implication that these figures are unique solutions for particular values of $K_{t}$. Bartholomé writes that " consideration is given only to the iron-magnesium ratio in the mineral involved, the calcium content being disregarded ". As will be demonstrated below, calcium content cannot be disregarded, and an assumption has to be made about the calcium contents before the diagrams can be drawn. These figures, together with their implication of a unique solution are reproduced uncritically by Collee $(1962$, p. 71$)$ and the same result is accepted by Oosterom (1962, p. 263).

Text-fig. 1 is the refutation of the hypothesis that tie-lines in the $\mathrm{Ca}-\mathrm{Mg}-\mathrm{Fe}$ projection and distribution coefficients are the same thing.

All points on $C d$ have a constant ratio of $\mathrm{Mg} / \mathrm{Fe}$. Similarly, all points on $C p$ have a different but constant ratio of $\mathrm{Mg} / \mathrm{Fe}$. Consequently for any pair of points in the projection such as $e$, representing a clinopyroxene composition, and $q$, representing a calcium-poor pyroxene composition, the distribution coefficient $K_{t}=\left(\frac{\mathrm{Mg}}{\mathrm{Fe}}\right)_{\mathrm{e}} \cdot\left(\frac{\mathrm{Fe}}{\mathrm{Mg}}\right)_{\mathrm{q}}=\frac{\mathrm{dF}}{\overline{\mathrm{Md}}} \cdot \frac{\mathrm{Mp}}{\mathrm{pF}}=\mathbf{a}$ constant, $k$, for any point $e$ on $C d$ paired with any point $q$ on $C p$. Hence there is no unique solution for the tie-line orientation and position of a coexisting pyroxene pair within this diagram unless the $\mathrm{Ca} / \mathrm{Ca}+\mathrm{Mg}+\mathrm{Fe}$ ratio of both pyroxenes is assumed. Conversely the calcium distribution between coexisting pyroxenes is a potent factor in affecting the distribution coefficients-consider for instance the effect 